\title{
Ile jest planet i dlaczego?
}

\author{
ANDRZEJ NIEDZIELSKI \\ Centrum Astronomii, \\ Uniwersytet Mikołaja Kopernika, Toruń \\ Andrzej.Niedzielski@astri.umk.pl
}

„Człowiek dąży do pełni poznania, gdyż jest istotą, która z natury szuka prawdy" (por. Fides et ratio, 28).

Streszczenie. Rozumienie pojęcia ,„planeta” zmieniało się z czasem. W miarę jak analiza planet i ich własności z zakresu filozofii przechodziła do nauk fizycznych pojęcie to krystalizowało się i stawało coraz lepiej zdefiniowane. Nawet dziś jednak nie do końca potrafimy powiedzieć czym jest tytułowa planeta, ani tym bardziej ile ich jest. Właściwe zrozumienie tego co astronomie określają pojęciem planety jest o tyle ważne, że dla wielu osób poszukiwania planet tożsame są z poszukiwaniem życia pozaziemskiego. Przedstawiony artykuł stanowi próbę konfrontacji współczesnej wiedzy na temat planet z historyczną ewolucją pojęcia.

Stowa kluczowe: astronomia; planety; planety pozasłoneczne.

Abstract. What is a planet and how many planets are there? A brief outlook of evolution of the concept of planet in astronomy and a very short summary of current status of extrasolar planet searches results are presented. It is shown that the concept evolved substantially between the ancient Greek ,,wandering star" and current understanding of these celestial bodies and in every epoch reflected current status of the development of physical sciences. However, planets are difficult objects to define and even these days we see evolution of the concept as perfectly illustrated by the history of Pluton and the planet-Brown Dwarf vague border. Obviously the public appreciates the current 
searches for planets around other stars as possible sources of information concerning alien life. In this context it is important to notice that common understanding of planets as the only possible cradles of such life is not correct and life may be appear to be present on other bodies as well.

Keywords: astronomy; planets; exoplanets.

\section{Wstęp}

Nie wiemy ani kto, ani kiedy po raz pierwszy zauważył jasne gwiazdy wędrujące (słowo planetes pochodzi z greki i oznacza „wędrująca”, a aster znaczy „gwiazda”) inaczej niż wszystkie pozostałe na naszym niebie. Wiemy natomiast, że już starożytni Grecy znali pięć ze znanych dziś najjaśniejszych planet: Merkurego, Wenus, Marsa, Jowisza i Saturna. Do grupy planet zaliczali oni także Księżyc i Słońce, co dawało ogólną ich liczbę siedem, a pomijali Ziemię, która w tym rozumieniu planetą nie była. Dociekania na temat przyczyn tak dziwnego zachowania planet oraz ich natury przez stulecia zajmowały rzesze filozofów i astronomów. Początkowo studia te ograniczały się do rozważań natury filozoficznej. Z czasem jednak, wraz z tworzącymi się podstawami nauk fizycznych stawały się coraz bardziej naukowe.

Odkrycie kolejnej planety zajęło astronomom bardzo dużo czasu, gdyż wymagało to znajomości poprawnego modelu Układu Słonecznego. Model taki jako pierwszy zaprezentował Mikołaj Kopernik (1473-1543). Toruński astronom obalił, jak wiemy, model kosmogoniczny opracowany przez Klaudiusza Ptolemeusza (100-168 n.e.), zawierający geocentryczny opis ruchu planet z wykorzystaniem deferentów i epicykli. Ten niezwykle skomplikowany model w rzeczywistości nie działał dobrze i aby go ratować należało go wciąż rozbudowywać, dodając nowe ruchy i skalując prędkości wzajemne poszczególnych jego elementów tak, by uzyskać względnie dokładny opis rzeczywistego ruchu obserwowanych ciał niebieskich. W czasach Kopernika odchyłki między modelem Ptolemeusza a obserwacjami były jednak już ogromne. Obserwowane przez Kopernika w roku 1497 w Bolonii zakrycie Aldebarana przez Księżyc spóźniło się o pół godziny! 
Wprowadzony przez Kopernika model heliocentryczny w sposób znacznie prostszy opisywał ruch planet jako konsekwencję złożenia ich ruchu wokół Słońca z ruchem Ziemi na jej orbicie wokółsłonecznej. Przeniesienie środka układu z Ziemi do Słońca można uznać za ostateczne odkrycie kolejnej planety w Układzie Słonecznym - Ziemi, a tym samym za odkrycie pierwszego układu planetarnego - Układu Słonecznego. Paradoksalnie obserwacje największego przeciwnika teorii Kopernika Tycho Brahe posłużyły Johannesowi Keplerowi (1571-1630) do ostatecznego potwierdzenia teorii Kopernika i sformułowania trzech praw ruchu planet. Model Kopernika wzmocniony teorią grawitacji Isaaka Newtona (1642-1726) pozwolił na odnalezienie kolejnych planet w Układzie Słonecznym w wyniku analizy odchyłek w ruchu orbitalnym znanych planet. Podobna metodyka stosowana jest do dziś także w poszukiwaniach planet poza Układem Słonecznym.

\section{Historia poszukiwań planet w Układzie Słonecznym}

Uran, szósta planeta w naszym Układzie była obserwowana przez cały szereg astronomów, zanim została formalnie odkryta. Już w roku 1690 John Flamsteed (1646-1719) zauważył to ciało i doniósł o tym fakcie, katalogując je jako gwiazdę, lecz ani on, ani kolejnych szesnastu innych astronomów nie zainteresowało się tym obiektem bliżej. Planetę tę ponownie obserwował szereg razy Piotr C. Lemonnier (1715-1799), a Tobiasz Mayer (1723-1762) wpisał ją po raz kolejny do katalogu gwiazd. Dopiero w roku 1781 William Hershel (1738-1822) uznał Urana za nową kometę, czym zainteresował Bocharta de Saron (1730-1794), który zidentyfikował w tym odkryciu nową planetę. Ciekawostką jest fakt, że Uran jest planetą widoczną gołym okiem, a mimo to od pierwszych wzmianek na jej temat do właściwej interpretacji minęło 171 lat obserwacji teleskopowych!

Po odkryciu Urana zwrócono większą uwagę na zaproponowaną przez urodzonego w Chojnicach Daniela Titiusa (1729-1796) w roku 1766 i spopularyzowaną przez dyrektora obserwatorium astronomicznego w Berlinie Johanna Elerta Bodego (1747-1826) mnemotechniczną metodę pozwalają- 
cą na ocenę odległości do kolejnych planet w Układzie Słonecznym. Reguła Titiusa-Bodego poprawnie przewidywała rozmiary orbity Urana, przeczuwała bowiem istnienie planety między Marsem a Jowiszem. Intensywne poszukiwania takiego ciała przyniosły w roku 1801 odkrycie Ceres przez Giuseppe Piazziego (1746-1826), a następnie Pallas, Juno, Vesty i Astrei. Do końca 1851 roku znaleziono 15 nowych ,,planet” w miejsce brakującej. Zaniepokoiło to Williama Hershela, który ocenił w roku 1802 rozmiary Ceres na około $260 \mathrm{~km}^{1}$, a Pallas na około $237 \mathrm{~km}^{2}$. Wydawało się to zdecydowanie za mało jak na planetę i kolejne obiekty odkrywane między orbitami Mara i Jowisza, w tak zwanym Pasie Głównym Planetoid (dziś znamy ich około 320 000) zaczęto nazywać ,,asteroidami” bądź po polsku ,,planetoidami”'. Ten banalny z pozoru krok ma jednak bardzo istotne konsekwencje. Otóż okazuje się, że nie każde ciało poruszające się na firmamencie inaczej niż gwiazdy astronomowie chcą nazywać planetą.

Warto w tym miejscu zauważyć, że zupełnie nieświadomie podobnego wyboru astronomowie dokonali w przypadku komet. Komety bowiem przez stulecia były obiektami kojarzonymi raczej ze zjawiskami atmosferycznymi, a nie astronomicznymi. Dopiero Tycho Brahe (1546-1601) ocenił w roku 1577 odległość do widocznej wtedy komety na cztery razy większą od odległości Ziemia-Księżyc. Co ciekawe, myśl o tym, że kometa może być ciałem krążącym wokół Słońca, odrzucali także Galileusz i Kepler. Kiedy wreszcie w 1681 roku uczeń Heweliusza, Georg Samuel Doerfel (1643-1688) na podstawie obserwacji komety Kircha z roku 1680 stwierdził, że komety krążą wokół Słońca po paraboli, a teoria grawitacji Newtona pozwoliła w roku 1687 spostrzeżenie to udowodnić, nikomu już nie przyszło do głowy, by komety nazywać planetami.

Innymi interesującymi obiektami, które dla odmiany utraciły swoją planetarną naturę, są księżyce. Starożytni Grecy nazywali naszego satelitę, Księżyc, planetą. Do odkrycia księżyców Jowisza w roku 1610 przez Galileusza był on jedynym znanym obiektem tego typu. Także Galileusz nowo odkryte ciała nadal nazywał planetami. Pierwszym, który zwrócił uwagę

1 Faktyczne rozmiary Ceres to $975 \times 909 \mathrm{~km}$.

2 Faktyczne rozmiary Pallas to $570 \times 525 \times 500 \mathrm{~km}$. 
na ten problem, był Christiaan Huygens (1629-1695), odkrywca Tytana, największego - jak sam pisał - z ,„księżyców” Saturna. Termin przez niego zastosowany wynikał z analogicznej roli Tytana krążącego wokół Saturna do tej, jaką pełni krążący wokół Ziemi Księżyc. Johannes Kepler wprowadził do literatury zamienny termin „satellita” i obecnie posługujemy się obydwoma. Co więcej, termin zaproponowany przez Keplera przyjął się także na okoliczność sztucznych ciał wysyłanych w przestrzeń kosmiczną wokół innych ciał, mamy zatem dziś satelity naturalne, czyli księżyce, oraz satelity sztuczne.

Widzimy, że między XVII a XIX wiekiem pojawiła się trochę inna niż starogrecka definicja planety. Zaczęto tak nazywać ciała o dostatecznie dużej masie krążące wokół Słońca na orbicie eliptycznej.

Za odkrywcę Neptuna uznajemy Johanna Gottfrieda Gelle (1812-1910) oraz Heinricha Louisa d'Arrest (1822-1875), którzy planetę tę zaobserwowali w 1846 roku na podstawie obliczeń jej położenia wykonanych rok wcześniej (1845) przez studenta astronomii Johna C. Adamsa (1819-1892) oraz nieco później Urbaina Le Verriera (1811-1877). Historia odkrywania tej planety przypomina nieco tę dotyczącą Urana. Bezwiednie obserwowali go bowiem wcześniej Józef L. Lalande (w 1795 r.) i Jan Lamont (w 1845 r.). Okazało się jednak, że istnienie tej planety nie wyjaśnia do końca odchyłek w ruchu Urana wyznaczonych na podstawie znajomości jego orbity przez Aleksandra Bouvarda (1767-1843). Rozpoczęto zatem poszukiwania kolejnej planety. Jej orbitę wyliczyli jako pierwsi Percival Lowell (1855-1916) i Edward Pickering (1846-1919), lecz Plutona zaobserwował wiele lat później Clyde W. Tombaugh (1906-1997) asystent Lowella w roku 1930 jako obiekt 15 wielkości gwiazdowej, widoczny dopiero na fotografiach nieba wykonanych przez teleskop. Pluton jest bardzo odległym od Słońca, bo znajdującym się 39,5 razy dalej niż Ziemia i stosunkowo małym ciałem o średnicy zaledwie około $2302 \mathrm{~km}$, mniejszym nawet od naszego Księżyca, którego średnica równikowa wynosi 3476 km.

Jednak to nie rozmiary zdecydowały o przyszłości Plutona. W miarę jak do powszechnego użytku w astronomii weszły cyfrowe odbiorniki, których działanie oparte jest na kamerach CCD, już za pomocą stosunko- 
wo niewielkich teleskopów stało się możliwe poszukiwanie dodatkowych ciał w naszym Układzie Słonecznym. Od około 1992 roku odkryto w okolicach orbity Plutona wiele podobnych do niego obiektów. Okazało się, że obiekty te tworzą za orbitą Neptuna pas podobny do Pasa Głównego Planetoid, tzw. Pas Kuipera. Tysiące małych ciał krążą tam na zbliżonych orbitach i w wyniku zderzeń między nimi niektóre wpadają do wnętrza Układu Słonecznego w postaci komet krótkookresowych. W szczególności znaleziono tam takie obiekty, jak Haumea (o średnicy ok. 1100 km) i Makemake (o średnicy ok. $1500 \mathrm{~km}$ ). Jeszcze dalej od Słońca znaleziono Eris (średnica około $2300 \mathrm{~km}$ ) i cały szereg podobnych obiektów, które czekają na bliższe zbadanie. Taki rozwój sytuacji skłonił astronomów do ponownego rozważenia terminu planety. W roku 2006 w Pradze Zgromadzenie Ogólne Międzynarodowej Unii Astronomicznej w drodze głosowania ustaliło, że planetą w Układzie Słonecznym będziemy nazywać obiekt, który spełni następujące trzy warunki: (1) krąży wokół Słońca, (2) ma kształt kulisty, gdyż posiada wystarczającą masę, by własną grawitacją pokonać siły spójności ciała sztywnego oraz (3) wyczyścił swoją orbitę z mniejszych bądź podobnych obiektów. Pluton nie spełnia warunku (3) i dlatego wraz z Humeą, Makemake oraz znaną nam już Ceres został określony mianem planety karłowatej. Jest wielce prawdopodobne, że lista tego typu obiektów będzie z czasem dłuższa. Nietrudno zauważyć, że próbując rozwiązać problem nazewnictwa ciał w Układzie Słonecznym związany z odkrywaniem coraz większej liczby małych ciał, astronomowie skupili się faktycznie na zdefiniowaniu najmniejszego obiektu, który jeszcze nazywać będziemy planetą.

\section{Planety poza Układem Słonecznym}

Tymczasem w astronomii zaszły rewolucyjne zmiany w zupełnie nowym kierunku. Już pod koniec lat 80. ubiegłego wieku astronomowie zaczęli odkrywać przy innych gwiazdach obiekty podobne do planet. Jednym z pierwszych doniesień na ten temat była praca D. Lathama i współpracowników z roku 1989, w której sugerowali oni istnienie nieznanego składnika orbi- 
tującego wokół gwiazdy typu słonecznego HD 114762. Obiekt ten mógłby być brązowym karłem ${ }^{3}$ lub masywną planetą o masie co najmniej 11 razy większej niż masa Jowisza (czyli około 3000 razy bardziej masywną niż Ziemia). Późniejsze badania B. Cochrana i innych z roku 1991 potwierdziły ten wynik i zebrane do dziś dane dowodzą, że mamy tu do czynienia raczej $\mathrm{z}$ brązowym karłem niż planetą.

Pierwszą planetę przy gwieździe innej niż Słonce, a równocześnie pierwszy pozasłoneczny układ planetarny wokół pulsara PSR 1257+12 składający się z trzech planet odkrył w roku 1992 Aleksander Wolszczan wraz z współpracownikiem D.A. Frailem. Wchodzące w jego skład obiekty charakteryzują się masami z całą pewnością w zakresie mas planetarnych znanych z naszego Układu Słonecznego, gdyż wynoszą od 0,025 do 4,3 masy Ziemi! Ten szczególny układ planetarny, krążący wokół ,„martwej” gwiazdy neutronowej, został odkryty całkowicie nietypową techniką opartą na superprecyzyjnych pomiarach radiowych. Technika ta jest bardzo rzadko stosowana, wymaga ona bowiem ogromnego nakładu czasu obserwacji oraz największego na świecie radioteleskopu, jak ten w Arecibo o średnicy czaszy 305 metrów, wykorzystany przez Wolszczana. Oczywiście w przypadku planet Wolszczana nie tylko technika jest nietypowa, również układ planetarny w tak nietypowym środowisku jest zagadką sam w sobie.

Dopiero po trzech latach od odkrycia Wolszczana i Fraila zespół astronomów szwajcarskich Michel Mayora i Didier Queloza odkrył planetę przy gwieździe podobnej do naszego Słońca. Odkryta w roku 1995 planeta na orbicie 51 Pegasi miała podwójnie przełomowe znaczenie. Po pierwsze, po raz pierwszy do detekcji planet poza Układem Słonecznym zastosowano z powodzeniem technikę precyzyjnych pomiarów prędkości gwiazd opartą na rozszczepionym za pomocą spektrografu świetle gwiazdy. Precyzja osiągana przez astronomów poszukujących planet przebiła dotychczasową o 100-1000 razy. Taka dramatyczna zmiana dokładności w pomiarach otworzyła zupełnie nowy horyzont dla badań. Technika ta, rozwijana od lat 60., wymaga co prawda stosowania stosunkowo dużych teleskopów i skom-

\footnotetext{
3 Więcej o brązowych karłach nieco dalej.
} 
plikowanych spektrografów, jednak już obecnie pozwala na pomiary prędkości gwiazd z dokładnością lepszą niż 1 metr na sekundę i w niezbyt odległej przyszłości może pozwolić na wykrywanie planet o masach podobnych do masy Ziemi. Odkrywanie planet stało się z czasem rutyną. Warto jednak pamiętać, że aby ruch gwiazdy będący odbiciem ruchu orbitalnego krążącej wokół niej gwiazdy był dla nas mierzalny, planeta musi krążyć na orbicie, która nie jest prostopadła do kierunku patrzenia obserwatora ziemskiego.

Drugi istotny przełom wynikający z odkrycia Mayora i Queloza to planeta krążąca wokół 51 Pegasi - ogromny obiekt, podobny do naszego Jowisza, ale krążący wokół swojego słońca na orbicie ciaśniejszej niż orbita Merkurego. Nikt nie spodziewał się takiej planety! $\mathrm{Z}$ czasem odkryto wiele tego typu planet - gorących Jowiszy - i stało się jasne, dlaczego wcześniejsze poszukiwania analogów naszego Jowisza, tzn. masywnych planet na rozległych orbitach, spełzły na niczym. Gorących Jowiszy jest bardzo dużo i stosunkowo łatwo je znaleźć. Kolejny raz naukowcy ponieśli konsekwencje braku wyobraźni.

To właśnie odkrycie przez Mayora i Queloza pierwszej planety orbitującej gwiazdę podobną do naszego Słońca spowodowało nieprawdopodobny wzrost zainteresowania planetami oraz rozkwit technik badawczych im poświęconych. Gdy było już jasne, że planety rzeczywiście krążą wokół innych gwiazd próbowano adaptować do ich poszukiwań znane już wcześniej techniki astrofizyki obserwacyjnej.

Stosunkowo łatwo można znaleźć planetę przy innej gwieździe wtedy, gdy jej orbita jest dokładnie równoległa do kierunku patrzenia obserwatora ziemskiego na tę gwiazdę. Okresowo zachodzą w takiej konfiguracji zjawiska przejścia planety na tle tarczy jej gwiazdy, z Ziemi obserwowane jako krótkotrwałe obniżenie całkowitego blasku gwiazdy, zazwyczaj o mniej niż $1 \%$. Obserwacje takiego zjawiska są zasadniczo bardzo proste i nie wymagają zastosowania dużych teleskopów. Ze względu jednak na szczególną i rzadką konfigurację orbity planety samo zjawisko jest niezmiernie rzadkie i aby efektywnie je wykrywać, należy równocześnie prowadzić obserwacje dziesiątków tysięcy gwiazd. Projekt taki nadaje się świetnie do realizacji za pomocą teleskopu umieszczonego na orbicie Ziemi, który dodatkowo 
będzie uwolniony od wpływu atmosfery i wynikających z jej istnienia ograniczeń. Faktycznie, teleskopy kosmiczne Corot i Kepler z powodzeniem znalazły setki planet w ten sposób.

Wymienione wyżej trzy techniki poszukiwań planet mają charakter pośredni. Faktycznie obserwujemy gwiazdy (ich jasność czy prędkość), które interpretujemy jako istnienie planet przez porównanie z odpowiednimi modelami matematycznymi zachodzącego zjawiska. Dużo łatwiej byłoby, gdyby planety przy innych gwiazdach można było wykrywać w sposób bezpośredni: na przykład zwyczajnie widząc je przy ich macierzystych gwiazdach. Niestety, gwiazdy znajdują się w ogromnych odległościach, planety krążące wokół nich świecą jedynie bardzo słabym, odbitym światłem swoich słońc, a ich orbity są dla nas w ogromnej większości przypadków zbyt mało rozległe, byśmy mogli światło emitowane przez planetę oddzielić od blasku gwiazdy. Jedynie w kilku szczególnych przypadkach udało się ogromne planety znaleźć przy małych i chłodnych gwiazdach, w optymalnej konfiguracji dla tej, bardzo ograniczonej naszymi technicznymi możliwościami techniki.

Zważywszy na nasze obecne techniczne ograniczenia, wyniki poszukiwań planet przy innych gwiazdach są zdumiewające. Znamy ich dziś setki. Okazuje się, że planety występują przy różnych gwiazdach. Zarówno przy takich, które przypominają nasze Słońce, jak i znacznie młodszych i starszych, bardziej i mniej masywnych. Również bogactwo planet, ale i architektur układów planetarnych okazało się niezwykłe. Poza wspomnianymi wyżej gorącymi gazowymi olbrzymami odkryto także zwyczajne gazowe olbrzymy, krążące z dala od swoich słońc, podobnie jak to obserwuje się w naszym Układzie Słonecznym w przypadku Jowisza, Saturna Urana i Neptuna. Odkryto także planety o znacznie mniejszych masach, podobne do planet skalistych obecnych w naszym układzie planetarnym (do grupy tej zaliczamy Merkurego, Wenus, Ziemię i Marsa, czyli planety o jądrach żelaznych). Orbity nowo odkrytych planet w innych układach są często niezwykłe. Okazało się, że układy planetarne nie muszą wyglądać jak Układ Słoneczny. Możliwe są sytuacje, w których płaszczyzny orbit są do siebie znacznie nachylone. Znamy także takie przypadki, gdy planeta krąży po orbicie w przeciwną stronę niż obraca się jej słońce. Fakty te wskazują na 
to, że obserwujemy układy planetarne na różnym stopniu ich ewolucji. Od młodych, dynamicznie niestabilnych konfiguracji, poprzez ustabilizowane stare układy aż do pozostałości po systemach zaburzonych silnie przez przemiany fizyczne zachodzące w centralnej gwieździe.

\section{Planety a brązowe karły}

W miarę odkrywania coraz to nowych planet astronomowie znów zostali zmuszeni, by zastanowić się nad tym, co to jest planeta. Kolejne odkrycia zaczęły bowiem przynosić planety o masach znacznie większych niż wydawało się możliwe do przyjęcia. Obiekty o masach 20, 30 czy 50 razy masywniejsze od Jowisza stały się problemem. Pojawiło się zatem pytanie o górną granicę masy planety. Astronomowie potrafią dobrze podać dolną granicę masy gwiazdy, ponieważ określa ją konkretny proces fizyczny. Jeśli obiekt jest dostatecznie masywny, by jego grawitacja wytworzyła w centrum temperaturę i ciśnienie wystarczająco wysokie, by zainicjować reakcje jądrowe przetwarzające wodór w hel, to obiekt taki nazywać będziemy gwiazdą. Taka graniczna masa zależy nieco od jego składu chemicznego i wynosi koło 70 mas Jowisza. Czy zatem każdy obiekt o masie poniżej tej granicy nazywać można planetą? Sprawa nie jest aż tak prosta. Badania takich mało masywnych obiektów pokazały, że istnieje cała ich grupa, która na pewien czas uruchamia reakcje jądrowego spalania litu (obiekty o masie powyżej 63 mas Jowisza) lub deuteru (obiekty o masie powyżej 13 mas Jowisza). Teoretycznie istnienie takich obiektów, nazwanych brązowymi karłami, przewidział Jil Tarter w roku 1975, a pierwszy raz zaobserwowano je w roku 1995, czyli mniej więcej w czasie, gdy zaczęto odkrywać planety.

Jak zatem rozróżnić masywne planety od brązowych karłów? Rzecz nie jest prosta i w szczególności nie jest jasne, czy sama Natura dzieli takie obiekty na różne typy. Aby sprawy uporządkować, astronomowie postanowili wrócić do podstaw i rozważyć, w jaki sposób takie mało masywne obiekty powstają. Uważa się, że brązowe karły, podobnie jak gwiazdy, powstają w wyniku kolapsu, a następnie fragmentacji ogromnego obłoku międzygwiazdowej materii gazowo-pyłowej o początkowych rozmiarach 
rzędu 100 lat świetlnych i masie rzędu miliona mas Słońca. Obłok taki zagęszcza się, nagrzewa i dzieli na coraz mniejsze części, z których powstają w końcu gwiazdy. Jeśli w podobny sposób powstają brązowe karły, to ich budowa wewnętrzna będzie adekwatna do budowy mało masywnych, a zatem chłodnych gwiazd. Będą to obiekty w pełni konwektywne, bardzo wolno stygnące. Takie obiekty głównie będą poruszały się swobodnie w przestrzeni międzygwiazdowej, lecz część z nich może krążyć wokół zwykłych, spalających wodór gwiazd, których pole grawitacyjne je uwięzi, gdy znajdą się dostatecznie blisko.

Jeśli natomiast rozważymy powstawanie planet, to obecnie astronomowie uważają, że planety rodzą się z materii wokół gwiazdowej, będącej pozostałością po tej, z której powstała gwiazda, ale uwięzionej na jej orbicie $\mathrm{w}$ formie dysku, nazywanego protoplanetarnym, o masie będącej zaledwie ułamkiem (około 10\%) masy gwiazdy. Możliwe wydają się dwa schematy powstawania planet w takim dysku. Najprawdopodobniej najważniejszym z nich jest akrecja jąder, powolne budowanie, ,,sklejanie” coraz większych obiektów, głównie z pojedynczych ziaren pyłu. Gdy zbudowane zostaną w odpowiedniej ilości ciała o rozmiarach rzędu kilometrów, zaczynają one oddziaływać grawitacyjnie i tworzą w końcu skalisty obiekt, który staje się planetą podobną do Merkurego, Wenus, Ziemi czy Marsa. Proces ten może trwać do kilku milionów lat. Siły grawitacji mogą spowodować, że część z takich skalistych obiektów zgromadzi także pozostały w dysku protoplanetarnym gaz, w wyniku czego wokół skalistego ,,jądra” planety powstanie dodatkowo stosunkowo szybko ogromna gazowa otoczka, tworząc ,,gazowego olbrzyma”, jak Jowisz, Saturn, Uran czy Neptun. Alternatywny proces, zapaść grawitacyjna, może w znacznie krótszym czasie spowodować powstanie masywnych planet, jednak efektywność tego procesu jest prawdopodobnie niższa. Obiekty powstałe w dysku protoplanetarnym z zasady krążyć będą wokół swojej gwiazdy. Wyjątkiem będą takie ciała, które w wyniku oddziaływań grawitacyjnych z innymi podobnymi do siebie zostaną „,wyrzucone” poza zasięg pola grawitacyjnego ich macierzystej gwiazdy i staną się obiektami swobodnie poruszającymi się w przestrzeni międzygwiazdowej. 
Jak widzimy, rozważania dotyczące powstawania obiektów mało masywnych prowadzą nas do konkluzji, że ciała, które powstają jako planety, mogą krążyć wokół gwiazd, przy których powstały albo poruszać się swobodnie w przestrzeni międzygwiazdowej. Ciała, które powstały w procesie podobnym do powstawania gwiazd, brązowe karły także mogą krążyć wokół zwykłych gwiazd, choć pewnie częściej będą samotne. Co więcej, w dyskach protoplanetarnych mogą powstawać obiekty podobne do brązowych karłów. Aby wprowadzić nieco porządku w świecie planet, astronomowie umówili się, że nie będą nazywać planetą obiektów swobodnie poruszających się w przestrzeni międzygwiazdowej niezależnie od tego, w jaki sposób one powstały. Pojęcie planety zostało zatem ograniczone do ciał krążących wokół gwiazd. Co więcej, aby odróżnić planety od brązowych karłów przyjęto zasadę, że planetą będziemy nazywać obiekt, który nigdy nie rozpalił we wnętrzu reakcji jądrowych, czyli o masie poniżej około 13 mas Jowisza. Taka umowa definiuje zatem maksymalną masę planety. Niestety, nie jest to definicja ścisła. Nadal do grona planet zaliczyć musimy obiekty o masie poniżej 13 mas Jowisza, które powstały w wyniku fragmentacji obłoku protogwiazdowego i które znalazły się na orbicie wokół gwiazdy. Wydaje się, że ostatecznym sposobem na potwierdzenie planetarnego charakteru najbardziej masywnych obiektów tego typu będą badania struktury wewnętrznej, ale do tego jeszcze bardzo daleko. Musimy się zatem pogodzić z brakiem dokładnej definicji planety i z pewną dozą niepewności w tym zakresie. Być może w przyszłości Natura pozwoli nam znaleźć odpowiedni klucz do oznaczania planet i umożliwi odpowiedź na zadane w tytule pytanie, a być może z czasem przestanie to być istotne.

\section{Koncepcja wielości światów}

Już Anaksymander z Miletu (ok. 610-546 p.n.e.), uczeń Talesa, autor pierwszego naukowego modelu świata, spekulował na temat nieskończoności Wszechświata i dopuszczał istnienie nieskończonej ilości światów. Podobny pogląd głosili atomiści, a w szczególności Demokryt (ok. 460-370 p.n.e.), któremu św. Hipolit przypisuje także myśl o ich różnorodności (ze słońcami i księżycami lub bez) oraz powstawaniu, ginięciu i zachodzących w nich 
zmianach. Tak daleko posunięte analogie między naszym a innymi światami nie znalazły swojego miejsca w podzielonym na dwie sfery modelu kosmologicznym Platona (427-347 p.n.e.) i Arystotelesa (384-322 p.n.e.). Eteryczny charakter innych ciał niebieskich wykluczał wielość światów podobnych do ziemskiego. Choć warto zauważyć, że wielość światów w modelu geocentrycznym była możliwa do pomyślenia dla Mikołaja z Oresme (1320-1382). Również dla Mikołaja z Kuzy (1401-1464), twórcy koncepcji rotacji Ziemi, odrzucającego hierarchiczny model Arystotelesa i postulującego nieskończoność Wszechświata brak innych istot obdarzonych intelektem był zastanawiający. Model matematyczny umożliwiający ponownie wielość światów przedstawił Mikołaj Kopernik (1473-1543), który wprowadził koncepcję środka ciężkości możliwą do zastosowania do wielu ciał niebieskich i przedstawił poprawny model Układu Słonecznego. Kopernik nadał też Ziemi status planety. Myśl tę rozwinął w formie daleko idących spekulacji na temat wielości światów Giordano Bruno (1548-1600). Wątpliwości rozwiał Galileusz, który prowadząc pierwsze obserwacje teleskopowe w roku 1610, dostrzegł 4 nowe „planety” krążące wokół nowego „środka ciężkości”, czyli księżyce Jowisza. Koncepcję wielości światów ugruntował model wirów Kartezjusza (1596-1650). Teoria grawitacji Newtona (1642-1726) dała modelowi temu kształt naukowy. Od czasów pierwszych obserwacji teleskopowych Galileusza wiemy, że żyjemy wśród wielu gwiazd, które z kolei tworzą galaktyki, jak udowodnił Edwin Hubble (1889-1953). Jednak przez stulecia problem istnienia planet przy innych gwiazdach pozostawał otwarty.

Obecnie problem wielości światów ma już zupełnie inne znaczenie. Dziś wiemy, że inne planety istnieją i problem z filozoficznego stał się naukowy. Wieloletnie badania planet w naszym Układzie Słonecznym pokazały, że inne światy mogą być bardzo niepodobne do naszego, a warunki panujące na innych planetach niekoniecznie prowadzą do powstawania życia. Spośród znanych dziś setek planet pozasłonecznych zdecydowana większość także wydaje się interesująca poznawczo, lecz raczej niezamieszkiwalna dla nas czy istot do nas podobnych.

Faktycznie nie mamy pojęcia, jakie warunki musi spełniać ekosystem, by pojawiło się w nim życie. Znamy jedynie jeden przykład - naszą Zie- 
mię. Nie wiemy nawet, czy życie na planetach niepodobnych do Ziemi jest możliwe. Możemy natomiast, znając historię powstawania życia na Ziemi, określić przynajmniej ogólnie warunki, które, jak się nam obecnie wydaje, winien spełniać ekosystem, by mogło powstać w nim życie podobne do ziemskiego. Ogólnie rzecz biorąc, wymagać winniśmy, by na planecie przez czas dostatecznie długi, aby mogło powstać życie, istniały warunki dla niego optymalne. Przyjęło się nazywać „obszarem zamieszkiwalnym” lub „ekosferą” taki zakres orbit planety, w którym na jej powierzchni może istnieć woda w stanie płynnym. Oczywiście tak ogólne pojęcie wymaga ogromnej ilości szczegółowych informacji o konkretnej planecie i jej atmosferze, ale także i o jej słońcu, by problem „zamieszkiwalności” w konkretnym wypadku rozważyć. Musimy wiedzieć, czy dana gwiazda będzie żyć dostatecznie długo, by planecie dostarczyć w miarę stałą ilość energii tak długo jak potrzeba. Musimy wiedzieć, czy atmosfera planety z jednej strony przepuszcza dosyć dużo energii, by pozwolić na ogrzanie jej dziennej powierzchni, a z drugiej, czy jest dostatecznie nieprzepuszczalna, by zgromadzone ciepło utrzymać po stronie nocnej. Definicja taka nakłada także pewne ograniczenia na kształt orbity planetarnej, ponieważ orbity zbyt eliptyczne mogą spowodować zbyt duże wahania temperatury na powierzchni planety, bądź wręcz okresowe jej wyjścia ze strefy zamieszkiwanej. Musimy w końcu wiedzieć, czy w skład atmosfery i powierzchni danej planety wchodzą odpowiednie pierwiastki, na bazie których może powstać i utrzymać się życie. Nietrudno zgadnąć, że po zastosowaniu do naszego Układu Słonecznego ekosfera obejmuje jedynie Ziemię. Definicja taka, choć wydaje się bardzo ogólna, nie wyczerpuje wszystkich konfiguracji, w których możliwe jest do wyobrażenia powstanie warunków potencjalnie sprzyjających życiu. W szczególności możliwe są inne mechanizmy, które podnoszą temperaturę powierzchni planety, nawet jeśli znajduje się ona poza ekosferą, jak na przykład siły pływowe w układzie planeta-księżyc, które mogą doprowadzić do wystarczającego podgrzania powierzchni księżyca, by istniała tam woda w stanie płynnym (z sytuacją taką być może mamy do czynienia na Europie, jednym z księżyców Jowisza). Warto też zauważyć, że w ramach tak ogólnie sformułowanej definicji ekosfery można spodziewać 
się także życia na księżycach innych planet znajdujących się w ekosferach swoich gwiazd.

Ilość możliwych konfiguracji, nawet jeśli ograniczymy się do poszukiwań warunków podobnych do tych, z jakimi mamy do czynienia na Ziemi, wydaje się ogromna. Dziś jednak rozważania te, ze względu na brak konkretnych faktów obserwacyjnych, pozostają w sferze fantazji naukowej. Pozostaje nam tylko czekać na rozwój wydarzeń i oczekiwać przełomu technologicznego, który być może kiedyś pozwoli nam badać planety przy innych gwiazdach tak, jak dziś badamy planety w Układzie Słonecznym.

\section{Zakończenie - poszukiwania planet w Toruniu}

Jednym z największych projektów badawczych poświęconych poszukiwaniom planet z wykorzystaniem precyzyjnych pomiarów prędkości radialnych gwiazd jest Pensylwańsko-Toruński Projekt Poszukiwań Planet realizowany za pomocą jednego z największych na świecie teleskopów Hobby-Eberly (HET) w Teksasie. W ramach tego projektu, będącego wynikiem współpracy Aleksandra Wolszczana z Uniwersytetu Stanowego Pensylwanii i Andrzeja Niedzielskiego z Uniwersytetu Mikołaja Kopernika w Toruniu podjęto w roku 2005 poszukiwania planet przy około 1500 gwiazd masywniejszych i starszych niż Słońce. Z czasem początkowa ogromna próbka badawcza gwiazd została ograniczona do około 1000 obiektów najlepiej dopasowanych do szczególnych ograniczeń teleskopu HET, a kilkuletnie obserwacje wyłoniły grupę około 300 gwiazd, przy których znaleziono obiekty o masach planetarnych. Prowadzone obecnie obserwacje mają na celu potwierdzenie planetarnego charakteru znalezionych towarzyszy oraz pełny opis ich orbit. W ramach projektu odkryto szereg intrygujących, egzotycznych układów planetarnych. W roku 2007 została odkryta 10 (chronologicznie) planeta przy tzw. czerwonym olbrzymie, gwieździe znacznie starszej niż nasze Słońce - HD 17092 b oraz pierwszy układ dwuplanetarny przy kolejnym olbrzymie - HD 102272 b, c. W roku 2009 zaprezentowaliśmy pierwszy znany układ zawierający dwa brązowe olbrzymy na orbicie wokół czerwonego olbrzyma - BD +20 2457 b, c, natomiast w 2012 planetę zbli- 
żoną masą do Jowisza w naszym Układzie Słonecznym - na 5-, 7-letniej orbicie wokół swojej gwiazdy. W tym samym roku przedstawiliśmy najciekawszy, jak dotąd, przykład układu planetarnego poddanego wpływowi ewolucji gwiazdy - BD+48 740 b, gdzie przedstawiliśmy dowody wskazujące na niedawne (w kosmicznej skali) pochłonięcie planety przez gwiazdę. Do dziś pensylwańsko-toruńska współpraca zaowocowała 13 planetami przy gwiazdach innych niż Słońce oraz dwoma doktoratami, a w najbliższych miesiącach opublikowane zostaną wyniki dotyczące szeregu kolejnych planet, w tym kilku układów wieloplanetarnych.

Chcąc czy nie chcąc Toruń odgrywa wielką rolę w poszukiwaniach planet. Rozpoczął je wielki torunianin - Mikołaj Kopernik, który planet oczywiście nie szukał, ale zrobił znacznie więcej: przedstawił pierwszy poprawny model układu planetarnego - naszego Układu Słonecznego. Kopernik odkrył też niechcący planetę - Ziemię, która utraciła status Centrum Świata i stała się w wyniku jego badań ,,zwyczajną” planetą. Po blisko 550 latach Aleksander Wolszczan, absolwent Uniwersytetu Mikołaja Kopernika w Toruniu odkrył pierwszy pozasłoneczny układ planetarny zapoczątkowując zupełnie nową erę badań astronomicznych. Od tego momentu wiemy już na pewno, że istnieją układy planetarne przy innych gwiazdach. Od tego momentu nie pytamy już czy istnieją inne światy, pytamy raczej o to, gdzie jest najbliższy świat podobny do naszego? Czy jest on zamieszkały? Jeśli tak, jak wyglądają jego mieszkańcy i czy kiedykolwiek ich spotkamy? W odpowiedzi na część z tych pytań być może pomogą badania prowadzone przez szereg innych toruńskich astronomów, między innymi projekt prowadzony przez niżej podpisanego we współpracy z Aleksandrem Wolszczanem.

\section{Bibliografia (do dalszej lektury)}

Perryman, Michael. 2011. The Exoplanet Handbook. Cambridge: Cambridge University Press.

Rybka, Eugeniusz. 1983. Astronomia ogólna. Warszawa: PWN.

Schneider, Jean. The Extrasolar Planets Encyclopaedia. http://www.exoplanet.eu/ Włodarczyk, Jarosław. 2012. Księżyc w nauce i kulturze Zachodu. Poznań: Dom Wydawniczy Rebis. 